\title{
PRISTINA LIBERTAS: LIBERTY AND THE ANGLO-SAXONS REVISITED*
}

\author{
By Julia Crick
}

\author{
READ I4 MARCH 2003
}

\begin{abstract}
The association between liberty and the Anglo-Saxons has been rendered mythical by later retellings, both in the Middle Ages and afterwards. This later history notwithstanding, it is argued here that liberty occupied a significant place in the early English documentary record. Originally part of the cultural and linguistic inheritance from late antiquity, the notion of liberty was deployed by English churchmen in defence of monastic freedom from the eighth century onwards, creating an archival legacy which was rewritten and imitated in later centuries, becoming fixed in institutional memory as fiscal and legal freedoms bestowed on the populations of monasteries and towns by pre-Conquest kings.
\end{abstract}

Liberty and the Anglo-Saxons once co-existed in happy equilibrium. As long as later Englishmen pictured the England of the Anglo-Saxons as the fount of the ancient constitution or cradle of the English nation they projected on to this apparently formative period their aspirations, liberty among them $;^{-1}$ from at least the seventeenth century to the twentieth historians, politicians and polemicists sought and found liberty in the preConquest past. The traces of their sentimental quest are unmistakable. Stubbs celebrated the Anglo-Saxon chronicle (in almost Ossianic terms) as 'The song of the people emulous of ancient glories, girding itself up for a strong and united effort after liberty.' ${ }^{\prime 2}$ Edward Freeman, on a lecture

* Versions of this essay were presented at seminars in Cambridge and Oxford in November 2000 and June 2002. Its final form owes much to questions, comments and advice offered by members of the audience at all three public readings. In addition I owe particular thanks to Jonathan Barry, Rosamond Faith, Nicholas Orme and Susan Reynolds who guided me on specific points, and to Sarah Hamilton, Bruce O'Brien, Julia Smith and Alexandra Walsham, who generously read drafts, shared expertise and provided strategic advice.

${ }^{1}$ Hugh A. MacDougall, Racial Myth in English History: Trojans, Teutons and Anglo-Saxons (Montreal, I982); Simon Keynes, 'The Cult of King Alfred the Great', Anglo-Saxon England, 28 (1999), 225-356, and below, n. 5. Liberty has been discussed by Eric Gerald Stanley, Imagining the Anglo-Saxon Past: The Search for Anglo-Saxon Paganism and Anglo-Saxon Trial by fury (Cambridge, 2000), II3-22; see also James Campbell, The Anglo-Saxon State (2000), I2.

${ }^{2}$ William Stubbs, The Constitutional History of England in its Origin and Development, 6th edn (3 vols., Oxford, I903), I, 233. 
tour of New England in I88I, invited his audience to view William 'the Great' as 'a friend disguised in the garb of an enemy' who by the Norman Conquest had ensured not the destruction but the preservation 'of English law, of English freedom, of all that makes England England'. ${ }^{3}$ More than two centuries earlier Thomas Hedley, addressing parliament in June I6Io, had defended the 'ancient freedom and liberty of the subjects of England' a status confirmed in Magna Carta but of much greater antiquity, rooted in 'the ancient laws and liberties of the kingdom' before the Norman Conquest. ${ }^{4}$ In the rhetoric of liberty we may detect something of the spirit which once fired the passion for Anglo-Saxon studies.

The Anglo-Saxon liberties to which Stubbs, Freeman and earlier Hedley appealed of course vanish on inspection. Hedley and the common lawyers divined in the pre-Conquest past freedoms derived from ancient law $;^{5}$ Freeman and Stubbs pursued a romantic quality intrinsic to the national character since the inception of the English as an island nation. ${ }^{6}$ Such rhetoric died with racial Anglo-Saxonism, alongside faith in the concrete manifestations of the spirit of liberty explored by its historians: the notion of free Englishmen and the village commonwealth, ${ }^{7}$ the protodemocratic credentials ascribed to the king's witan. ${ }^{8}$ Liberty has been

${ }^{3}$ Edward A. Freeman, Lectures to American Audiences, I: The English People in its Three Homes; II: The Practical Bearings of General European History (Philadelphia, I882), I53. On this text see now William M. Aird, 'Edward A. Freeman in America and "The English People in their Three Homes", Haskins Society fournal, forthcoming.

4 'For I do not take Magna Carta to be a new grant or statute, but a restoring or confirming of the ancient laws and liberties of the kingdom, which by the conquest before had been much impeached or obscured': Proceedings in Parliament I6ro, ed. Elizabeth Read Foster (I966), II, I9o; cited by Paul Christianson, Discourse on History, Law and Governance in the Public Career of John Selden, I6IO-I635 (Toronto, I996), 31.

5 J. G. A. Pocock, The Ancient Constitution and the Feudal Law: A Study in English Historical Thought in the Seventeenth Century (Cambridge, I957); William Klein, 'The Ancient Constitution Revisited', in Political Discourse in Early Modern Britain, ed. Nicholas Phillipson and Quentin Skinner (Cambridge, I993), 23-44; Richard Tuck, 'The Ancient Law of Freedom: John Selden and the Civil War', in Reactions to the English Civil War I642-I649, ed. John Morrill (I982), I37-6I; Paul Christianson, 'Ancient Constitutions in the Age of Sir Edward Coke and John Selden', in The Roots of Liberty: Magna Carta, Ancient Constitution, and the Anglo-American Tradition of Rule of Law, ed. Ellis Sandoz (I993), 89-I46.

${ }^{6}$ See further MacDougall, Racial Myth, 89-I03, esp. 96-го2.

7 Analysed by J. W. Burrow, " "The Village Community" and the Uses of History in Late Nineteenth-Century England', in Historical Perspectives: Studies in English Thought and Society in Honour of f.H. Plumb, ed. Neil McKendrick (1974), 255-84.

${ }^{8}$ For a late endorsement of this view from a highly authoritative hand see F. Liebermann, The National Assembly in the Anglo-Saxon Period (Halle, I9I3). On Anglo-Saxonism see MacDougall, Racial Myth; Allen J. Frantzen, Desire for Origins: New Language, Old English, and Teaching the Tradition (1990), esp. 27-6r; Allen J. Frantzen and John D. Niles, 'Introduction: Anglo-Saxonism and Medievalism', Anglo-Saxonism and the Construction of Social Identity (Gainesville, I997), I-I4. 
effectively eliminated from the vocabulary of Anglo-Saxon studies. ${ }^{9}$ But alongside these relatively familiar expressions of national sentiment, now long gone, there lies a much earlier, medieval tradition, an ascription to pre-Conquest origins of freedoms of a different sort. Strictly speaking the connection between this and later manifestations remains entirely superficial - this earlier kind of liberty belongs to a cultural and conceptual universe remote from those of later constructions of personal and constitutional liberty. ${ }^{\text {Io }}$ It embraces privilege licensed by kings, a right claimed for institutions, an abstraction of a sort but more circumscribed and concrete in nature than the freedoms later claimed. But Anglo-Saxon liberty in its medieval guise resembles the later manifestations of liberty claims in one particular: it appears to function as an origin myth, a sought-after quality anachronistically attributed pre-Conquest origins. It is this rhetorical and historical tradition which I wish to explore.

Some years ago Sir James Holt traced the seventeenth-century theory of English constitutional liberties to Magna Carta and before, to what he described as 'an earlier antiquarian movement in the late twelfth century' when 'monks were developing a new interest in the English past to replace the wary hostility with which they had regarded the traditions of the conquered English hitherto'. ${ }^{\text {II }}$ In so doing he challenged a point of origin embedded in the historical literature and beckoned students of liberty further back into the Middle Ages. ${ }^{12} \mathrm{He}$ also argued for strong connections between the Ancient Constitutionalists of the seventeenth century and medieval texts, suggesting that the medieval textual authority used by Coke contained a 'parent myth' of pre-Conquest constitutional origins. ${ }^{13}$ In locating a tradition of Anglo-Saxon liberties in the twelfth century Sir James pursued the constitutional not the institutional tradition to be explored in this essay. Nevertheless, his study prefigures the present one

${ }^{9}$ Although, for a dissenting voice, as Bruce O'Brien has reminded me, see Campbell, The Anglo-Saxon State, xxix.

${ }^{10} \mathrm{On}$ the problems of translating notions of freedom from the classical to the medieval 'thought-world' see Brian Tierney, 'Freedom and the Medieval Church', in The Origins of Modern Freedom in the West, ed. R. W. Davis (Stanford, I995), 65.

" J. C. Holt, 'The Origins of the Constitutional Tradition in England', in Magna Carta and Medieval Government (1985), I-22, at 8.

${ }^{12}$ On the notion of Magna Carta as a point of origin see Sir Herbert Butterfield, Magna Carta in the Historiography of the Sixteenth and Seventeenth Centuries, Stenton Lecture I968 (Reading, I969); Anne Pallister, Magna Carta: The Heritage of Liberty (Oxford, 197I); Magna Carta and the Idea of Liberty, ed. James C. Holt (1972); Christopher W. Brooks, 'The Place of Magna Carta and the Ancient Constitution in Sixteenth-Century English Legal Thought', in The Roots of Liberty: Magna Carta, Ancient Constitution, and the Anglo-American Tradition of Rule of Law, ed. Ellis Sandoz (1993), 57-88.

${ }^{13}$ 'What mattered in the seventeenth century was not so much that Coke regarded the common law as ancient, but that he buttressed his view with tales and texts which already embodied the myth in a parent myth of their own': Holt, 'The Origins of the Constitutional Tradition', I7. 
in two respects. It connected seventeenth-century antiquarian tradition with that of the twelfth; $; 4$ it highlighted the importance of written and documentary tradition in the medieval construction of pre-Conquest liberty. The existence of rival constructions should occasion no surprise. The pairing of Anglo-Saxons and liberty has proved susceptible to invention and reinvention over many centuries. In looking beyond the constitutional tradition of Anglo-Saxon liberty to institutional claims, however, a more radical periodisation emerges: pre-Conquest evidence comes into contention. This present study will suggest that the rhetoric of liberty, although dormant for long periods, never went away at all, or at least not very far. ${ }^{15}$

The pristine liberty of my title, an original freedom ('pristina libertas') derived from Anglo-Saxon antiquity, belongs to polemic not only of the seventeenth century, but of the twelfth. ${ }^{16}$ The liberty in question concerned not the nature of royal prerogative and parliamentary redress as it might have done in a later age, but a grant of fiscal freedom allegedly made on the eve of the Norman Conquest in which Edward the Confessor restored to Westminster Abbey its original liberty previously renewed in the tenth century by his grandfather, King Edgar, Archbishop Dunstan and later by his father, Ethelred. ${ }^{17}$ The justice of the claims need not concern us here - for the purposes of the present argument I shall adopt a deliberately agnostic stance towards the question of the substance of claims to special privilege - but in appealing to ancient royal concessions as protection from current burdens the monk of Westminster who created the document in the twelfth century worked within a paradigm well rehearsed by his contemporaries. Henry I had publicly invoked preConquest precedent when, in his coronation charter, he declared a return to the laws of Edward the Confessor. ${ }^{18}$ Virtually from the time of the Conquest English monastic writers had claimed pre-Conquest freedom of a very specific sort, that their institutions should enjoy special freedom from interference - libertas - because of privileges granted by AngloSaxon kings, sometimes long dead. Such liberty sanctioned freedom from

${ }^{14}$ For other examples of the same linkage see Stanley, Imagining the Anglo-Saxon Past, I32-5, and Bruce R. O'Brien, God's Peace and King's Peace: The Lawes of Edward the Confessor (Philadelphia, I999), I23-6.

${ }^{15}$ For a brief discussion of liberty on either side of the Middle Ages see Quentin Skinner, Liberty before Liberalism (Cambridge, 1998).

${ }_{16}$ The term 'pristine liberty' was employed, for example, by John Hall in I7oo: quoted by Skinner, Liberty before Liberalism, 20.

${ }^{17}$ 'Resolutum est coram me, et recitatum de terribili loco, qui uulgo ab incolis Westmynster nuncupatur, qualiter auus meus Eadgarus et Dunstanus archiepiscopus et postea Ethelredus pater meus renouauit suam pristinam libertatem.' Anglo-Saxon Charters: An Annotated List and Bibliography, ed. P. H. Sawyer (1968) [hereafter S], no. Io4o.

${ }^{18}$ On which see O'Brien, God's Peace, and Patrick Wormald, The Making of English Law: King Alfred to the Twelfth Century, I: Legislation and its Limits (Oxford, I999), 400-I. 
certain forms of jurisdiction or taxation and in their most developed form the zones thus created, sometimes known as liberties, became islands of private jurisdiction, free from interference by the king's or bishop's men. These semi-autonomous zones had no direct pre-Conquest precursors; indeed the specific rights by which they were defined had no meaning in a pre-Conquest context, but many special freedoms were defended using alleged Anglo-Saxon precedent, none the less. Thus, in the twelfth century many religious foundations claimed special liberties bestowed in Anglo-Saxon antiquity, documenting their case using the diplomas of preConquest kings, the charters of founders and benefactors, improved or even created for the purpose. The monks of Ely appealed to King Edgar (957-75), those of Bury St Edmunds to Edward the Confessor (IO42$66)$, while the community of Evesham sought more ancient authority in Bishop Ecgwine of Worcester $(693 \times 7 \mathrm{I} 7) .{ }^{19}$

This pattern, the ascription of institutional freedoms to Anglo-Saxon origins, has acquired such familiarity as to have become almost banal, reproduced with drab predictability throughout the monastic record. Those who have drawn attention to it in recent years have done so often to stress its inauthenticity. The climate of production hardly suggests otherwise. Medieval Europe supplies many examples of collective retrospection in the wake of conquest, rights claimed in conquered territory said to derive from 'those days', the time before conquest. ${ }^{20}$ In England in particular, monastic writers bristled with defiant nostalgia for the pre-Conquest past on behalf of their own institutions and the English in general; Richard of Ely, for example, writing in the mid-twelfth century, described the fenlanders' heroic resistance to William the Conqueror in terms of defence of their homeland and their fathers' freedom (libertas). ${ }^{21}$ One might speculate further that this ancient trope of lost freedom, otherwise expressed as absence of oppression, finds unlikely reinforcement

${ }^{19}$ On these examples and others see Julia Crick, 'Liberty and Fraternity: Creating and Defending the Liberty of St Albans', in Expectations of the Law in the Middle Ages, ed. Anthony Musson (Woodbridge, 200I), 9I-IO3, esp. 95-6. See also below, nn. 28, 29. See also Nigel Berry, 'St Aldhelm, William of Malmesbury and the Liberty of Malmesbury Abbey', Reading Medieval Studies, I6 (1990), I5-38.

${ }^{20}$ Robert Bartlett, The Making of Europe: Conquest, Colonization and Cultural Change 950-I350 (Harmondsworth, I993), 93-5. See also M. T. Clanchy, 'Remembering the Past and the Good Old Law', History, 55 (I970), I65-76; Paul Brand, "Time out of Mind": The Knowledge and Use of the Eleventh- and Twelfth-Century Past in Thirteenth-Century Litigation', Anglo-Norman Studies, I6 (I993 [I994]), 37-54.

${ }_{21}$ 'in defensionem patriae et paternae libertatis': Lestorie des Engles solum la translacion Maistre Geffrei Gaimar, ed. T. D. Hardy and C. T. Martin (Rolls Series I888-9), I, 374 (Gesta Herwardi, attributed to Richard of Ely). On resentment more widely see, for example, M. T. Clanchy, England and its Rulers IO66-I272, 2nd edn (Oxford, I998), $3^{\mathrm{I}-4}$. 
in some modern historiography of Norman government. ${ }^{22}$ Whatever the cause, we may report as a fact a pronounced historiographical trend: postConquest presumption of pre-Conquest liberty has registered in recent printed discussion primarily as an artefact of immediate circumstances, a 'camouflage for direct economic and social interests', a construction of 'a sort of Christian citizenship'. ${ }^{23}$ In short, it has been possible to conclude that 'the manufacture of so many fraudulently ancient liberties implies that something in the post-conquest climate was creating a new demand for them'. ${ }^{24}$

We have indeed come to understand much of what drove the appeal to ancient liberties after the Norman Conquest - the need for defence against secular and ecclesiastical predators, the imperative to define and delineate rights and privileges, the whiff of legalism in the monastery. ${ }^{25}$ But by treating the evidence of this medieval hope as inert or transparently inauthentic, we are missing something. The rhetoric of liberty is a history not simply of absence, of relative lack of lordship, but of something more concrete. Scant attention has been paid to the process of construction, to the repeated invocation of ancient libertas as a hedge against encroachment, to its deployment as a defence in time of need. This body of so-called bogus material attests the existence of a historical paradigm of some tenacity, significant in the number of occasions on which it was invoked and also in their chronological range; from at least the eleventh to the seventeenth century groups defended rights by appealing to liberties rooted in the pre-Conquest past. Like the grandest medieval historical myths, therefore, like Arthur's imperial exploits, or the Trojan foundation of the French nation, Anglo-Saxon liberty outlived the Middle Ages. Like post-medieval historical ideas, furthermore, ours can claim to have enjoyed 'social circulation': ${ }^{26}$ the notion escaped its original confines to be perpetuated in a variety of forms, narrative and documentary, and it enjoyed a currency among illiterate as well as literate. The story of AngloSaxon liberty as an institutional construct thus merits consideration as a cultural phenomenon of some significance.

\footnotetext{
${ }^{22}$ Although for trenchant opposition to this line of argument see Campbell, The AngloSaxon State.

${ }^{23}$ Alain Boureau, 'How Law Came to the Monks: The Use of Law in English Society at the Beginning of the Thirteenth Century', Past and Present, 167 (2000), 29-74, esp. 70-2.

${ }^{24}$ Patrick Wormald, 'Frederic William Maitland and the Earliest English Law', Law and History Review, I6 (1998), I-25, reprinted in his Legal Culture in the Early Medieval West: Law as Text, Image and Experience (1999), 45-69, at $5 \mathrm{I}$.

${ }^{25}$ Above, nn. 23-4.

${ }^{26}$ The term was coined in a post-medieval context: Daniel Woolf, The Social Circulation of the Past: English Historical Culture I500-I730 (Oxford, 2003), 9.
} 


\section{Medieval liberty}

The evidence for the medieval trope of pre-Conquest liberty spills out of the familiar narratives and records of later medieval monasticism. ${ }^{27}$ Individual incidents are well known, indeed notorious, but the collective evidence has not, to my knowledge, ever been assembled and I shall not attempt to do more than outline some examples here. More than forty medieval English houses kept in their archives documents in which pre-Conquest donors, usually kings, purportedly bestowed liberties on the institution concerned or certain of its estates. This reservoir of documentation, much of it spurious, could be drawn on as needs dictated. In 1275 when the abbot of Glastonbury needed to defend his claim to return of writs, he invoked charters from the time of Ine, king of Wessex (688-726). ${ }^{28} \mathrm{~A}$ decade later, in ${ }^{2} 287$, the abbot of St Albans defended the same privilege in the name of Offa of Mercia $(757-96) \cdot{ }^{29}$ Thus thirteenth-century abbots invoked precedents established by the rulers of long-defunct polities to defend rights not formulated until after the Norman Conquest: the incongruities speak for themselves. As late as I4I5, or so it has been argued, a monk of Crowland cited forged Anglo-Saxon charters in order to defend his monastery against nearby Spalding in a dispute about fishing rights. ${ }^{30}$ These charters appear in the chronicle of pseudo-Ingulph and are laden with references to libertates..$^{31}$ Later still, in I486, the abbot of Abingdon's claims to libertas at his estate at Culham were contested during a trial for high treason after the defendant, Humphrey Stafford, had attempted to elude arrest by sheltering there.

${ }^{27}$ Roger of Wendover, Chronice sive Flores historiarum, ed. H. O. Coxe (I84I-4), I, 258-62, II, I6I-4; Chronicon Abbatiae de Evesham, ed. W. D. Macray (Rolls Series I863); Memorials of St. Edmund's Abbey, ed. Thomas Arnold (Rolls Series I89o-6), I, 6o-7 (Hermann, Miracula, chs. 25-9); Willelmi Malmesbiriensis monachi De Gestis Pontificum Anglorum, ed. N. E. S. A. Hamilton (Rolls Series I870), 378-8I (William of Malmesbury, Gesta pontificum, v, 225-6, discussed by Berry, 'St Aldhelm'). For further examples and discussion see David Knowles, 'Essays in Monastic History, IV - The Growth of Exemption', Downside Review, 50 (I932), 20I-3I, although some of his judgements have been superseded by subsequent work. See Patrick Wormald, below, n. 49 .

${ }^{28}$ Helen Cam, Law-Finders and Law-Makers in Medieval England: Collected Studies in Legal and Constitutional History (New York, I963), 4I n. 2. For references and discussion see Crick, 'Liberty', 95-6.

${ }^{29}$ Cited by Brand, " "Time out of Mind"', 38-9. For examples of appeal to alleged preConquest precedent by tenants see Rosamond Faith, 'The "Great Rumour" of I377 and Peasant Ideology', in The English Rising of I38I, ed. R. H. Hilton and T. H. Aston (Cambridge, I984), 43-73, esp. 56-8.

${ }^{30}$ Daniel Williams, 'The Crowland Chronicle, 6r6-I500', in England in the Fifteenth Century: Proceedings of the 1986 Harlaxton Symposium, ed. Daniel Williams (Woodbridge, 1987), 371-90 at 375. On the sources of the compilation see David Roffe, 'The Historia Croylandensis: A Plea for Reassessment', English Historical Review, i Iо (I995), 93-го8.

${ }_{31}$ Ethelbald's charter freed the monks from all secular burdens on the estates given which were granted 'cum omnibus libertatibus et liberis consuetudinibus': S 82. 
The abbot defended his right to offer sanctuary using a charter purporting to be a grant made by Coenwulf, king of Mercia, in 82I. The charter, in fact a twelfth-century forgery, was not enough to save Stafford: he was executed. ${ }^{2}$

What this stock of supposed pre-Conquest material sometimes lacked in efficacy it made up for in versatility. Indeed, the symbolic and monetary value of Anglo-Saxon liberty attracted imitators, not just among religious houses. Towns, too, adopted the paradigm. ${ }^{33}$ One of the most famous examples of appropriated claims to Anglo-Saxon liberty comes from the Peasants' Revolt. ${ }^{34}$ When the mob marched on the abbey of St Albans on the morning of Saturday I5 June I38I, they reportedly demanded the release of documents, in particular those concerning their freedoms, libertates. The abbot allegedly complied, handing over rolls and charters from the monastery's archives which the rebels burned in the marketplace immediately outside the abbey's gates. According to Walsingham, the house historian, the crowd was still not satisfied. They demanded a certain ancient charter concerning the liberties of the townsmen, which was decorated with blue and gold capitals. ${ }^{35}$ When the abbot proved unable to produce it they stormed the monastery and began looting. The ancient charter which had eluded the abbot so is commonly referred to as a charter of Offa and Walsingham records that the townsmen claimed that the liberties which they sought had been bestowed on them by King Offa. ${ }^{36}$ Given that forged privileges of Offa had secured exceptional privileges for the monastic community, not least the formal delineation of their liberty extracted from the papal curia, this is a request of some interest. In rhetorical terms at least, the townsmen fought or were obliged to fight on their oppressor's ground. They voiced their desires and aspirations in terms laid down by their opponents in writing and championed by them for centuries. For town and monastery Offa was the originator of liberties, whatever mixed messages were thereby encoded. ${ }^{37}$

\footnotetext{
${ }^{32} \mathrm{~S}$ I84. Charters of Abingdon Abbey, Part I, ed. S. E. Kelly, Anglo-Saxon Charters VII (Oxford, 2000), xlv and 48 .

${ }^{33}$ On the connection between the legal claims of towns and monasteries in the postConquest period see O'Brien, God's Peace, II 2-I3.

${ }^{34}$ See, for example, Faith, 'The "Great Rumour"', 64-5; Steven Justice, Writing and Rebellion: England in 138I (1994).

35 Thomae Walsingham Historia Anglicana, ed. Henry Thomas Riley (Rolls Series I863-4), 475 .

${ }_{36}^{6}$ Gesta abbatum Monasterii Sancti Albani, ed. Henry Thomas Riley (Rolls Series I867-9), III, 365 .

${ }^{37}$ Note that Offa was seen to have liberated the institution and to have guaranteed the liberation of the people. For discussion of tenants' use of archival material see Faith, 'The "Great Rumour"'. On comparable instances of rhetorical appropriation see J. G. A. Pocock, 'The Concept of a Language and the métier d'historien: Some Considerations on Practice',
} 
Wherever credible, then, monasteries and towns claimed and sometimes won liberties rooted in the pre-Conquest past. Established by the early twelfth century, the pattern continued as long as the monasteries survived. Even after the Reformation altered or expunged the institutions for which the notion had been developed, Anglo-Saxon liberty lived on. A charter purporting to be a grant of 'perpetual liberty' made by King Cnut in Iorg to the abbot and brethren of St Mary's Exeter in Ior9 was presented for royal confirmation four times in the sixteenth century, twice after the reformation of the cathedral, and was copied a further four times in the post-medieval centuries. ${ }^{38}$ At a time when medieval records were being scoured in the pursuit of civic dignity, privilege and title to former monastic property, an ancient document such as this, freeing the monastery and its property from royal and secular exaction, certainly deserved notice. ${ }^{39}$ Towns continued to invoke Anglo-Saxon liberties by charter later still. Since at least the fourteenth century, the burgesses of Malmesbury had been in possession of an undated charter purporting to demonstrate that King Athelstan (925-39) had restored to their tenthcentury predecessors free customs originally granted by his father, Edward the Elder. ${ }^{4}$ After the Middle Ages, interested parties, presumably the citizens of Malmesbury, sought and obtained royal confirmation on a number of occasions, the last under James I, at a time when Malmesbury was in dispute with its neighbours..$^{4 \mathrm{I}}$ Other forged pre-Conquest charters staking claims to liberties attracted a comparable surge in interest after Dissolution. ${ }^{42}$ Not only could the stock be replenished, new uses could be found for it.

in The Languages of Political Theory in Early-Modern Europe, ed. Anthony Pagden (Cambridge, 1987), 19-38, at 24 .

${ }^{38} \mathrm{~S}$ 954. Charters of Exeter, ed. C. Insley, Anglo-Saxon Charters (Oxford, forthcoming), no. 24 , MSS J, L, M, N, O, R, S, W, X.

39 'hanc cartulam concedo... ad perpetuam libertatem, ut liberum permaneat ipsum monasterium cum omnibus prediis illi concessis, et cum omnibus rebus ad eum rite pertinentibus... ab omni regali et seculari grauedine maiora aut minora... nisi sola expeditione et pontis constructione'. On the search for medieval precedent for the status of towns see Robert Tittler, The Reformation and the Towns in England: Politics and Political Culture, c. $1540-1640$ (Oxford, I998), 281-3.

${ }_{40}$ 'quod habeant et teneant semper omnes functiones et liberas consuetudines suas sicut tenuerunt tempore regis Eduuardi patris mei': S 454. Charters of Malmesbury Abbey, ed. S. E. Kelly, Anglo-Saxon Charters (Oxford, forthcoming), no. 36.

${ }^{41}$ Confirmation Rolls 2 James I, pt 2, no. I4. The dispute is mentioned by Tittler, The Reformation and the Towns, 205.

${ }^{42}$ Alleged (spurious) pre-Conquest grants of liberty were much copied after the Middle Ages: twelve of a total of forty-two copies of Edgar's grant of liberties to Ely (S 779) date from the sixteenth century or later, likewise twelve of twenty-three copies of Edgar's grant to Thorney (S 792), and eight of thirty-two copies of Cnut's grant to Bury in which he is made to renew King Edmund's original gift of liberty $(\mathbf{S} 980)$. On the early modern copying of forged pre-Conquest charters see Julia Crick, 'The Art of the Unprinted: Transcription 


\section{Across the Conquest}

Anglo-Saxon liberty, then, was deeply rooted in the historical consciousness of English institutions in the later Middle Ages and beyond. Monasteries and towns cultivated fond memories of Anglo-Saxon kings who, as founders and patrons, dished out grants of libertas, a commodity ill-defined and thus unencumbered by historical baggage, of enduring value in fending off new threats. They kept in their archives testimony to this effect, overwhelmingly forged, which they had validated periodically by royal confirmation. This deference to pre-Conquest founders and patrons suggests the cultivation of historical memory of some vigour, but what kind of phenomenon was this? Through what channels did it develop? Clearly it was perpetuated by competition and imitation, much like national origin stories: once the Franks had staked a claim to Trojan origins, their rivals followed suit. ${ }^{43}$ Arguably the notion of Anglo-Saxon liberty outgrew its original boundaries and escaped into rumour and oral tradition, as reportedly it did at St Albans. ${ }^{44}$ But studies of national origin stories stress the careful cultivation of such traditions: they grow from seeds deliberately planted. ${ }^{45}$ It could certainly be argued that examples of claims to Anglo-Saxon liberty emanating from monastic, and sometimes also urban, communities had no connection with pre-Conquest tradition. Did they, like later constructions of Anglo-Saxon liberty, rest on little more than wishful thinking?

There are a number of reasons why one might believe this. Mayke de Jong recently alluded to the search for an authoritative past inherent within Christianity, particularly medieval Christianity. ${ }^{46}$ Parallel to this notion, and perhaps illustrative of it, is the tendency of the members of institutions in the Middle Ages and later to seek the oldest possible precedent for any privilege sought. We have become attuned to the allure exercised in the remote past in the Middle Ages, the unseemly races for antiquity pursued in particular by those charged with protecting the dignity and upholding the claims of nations, which brought Egyptians to Scotland and Joseph of Arimathea to Somerset. ${ }^{47}$ For an institution such

and English Antiquity in the Age of Print', in The Uses of Script and Print, I30o-I70o, ed. Julia Crick and Alexandra Walsham (Cambridge, 2004), iा6-34.

${ }^{43}$ Susan Reynolds, 'Medieval Origines gentium and the Community of the Realm', History, 68 (1983), 375-9o.

${ }^{44}$ Compare Justice's account of the effects of writing in mobilising the St Albans rebels: Writing and Rebellion, I3-66. Also Faith, 'The "Great Rumour".

${ }^{45}$ R. R. Davies, 'The Peoples of Britain and Ireland, I I0o-I400: I Identities and Peoples', ante, sixth series, 4 (1994), 2.

${ }^{46}$ Mayke de Jong, 'Religion', in The Early Middle Ages: Europe 40o-Iooo, ed. Rosamond McKitterick (Oxford, 200I), I32.

${ }^{47}$ For example, Bruce Webster, 'John of Fordun and the Independent Identity of the Scots', in Medieval Europeans: Studies in Ethnic Identity and National Perspectives in Medieval Europe, ed. 
claims had to be narrowly focused and to abide by certain rules: they had to pass muster among contemporaries. Association with a founder suggests that the rights claimed are intrinsic to the institution: it never existed without them. We have seen this kind of logic displayed in the competing claims of town and abbey connected with Offa, hailed by both sides as the founder of their liberties. Thus it might be natural for post-Conquest historians to seek to press back to the time of foundation the closest fought and most dearly held claims of an institution. For many monasteries this meant Anglo-Saxon kings.

A second reason for thinking post-Conquest claims to Anglo-Saxon liberty manufactured has already been mentioned: the charters which make the case most eloquently are, without exception, forged. In recent years, Patrick Wormald has been emphatic on this point: 'It is not just that those who postulate extensive pre-Conquest immunities must depend on dubious texts. The very prevalence of such fabrications may say something about the urgency that the issue was assuming in the post-Conquest world. ${ }^{3{ }^{8}} \mathrm{He}$ ruled out the existence of any authentic evidence for extensive grants of liberty before the Conquest, with the possible exception of a single writ, and cited cautionary tales of scholars misled by spurious charters. ${ }^{49}$

There is a third reason for scepticism about pre-Conquest antecedents to later claims to liberty in England. Liberties in their twelfth-century form, as designated zones immune from outside interference, are indeed a post-Conquest phenomenon. Libertas ecclesiae was a slogan of the reforming papacy of the eleventh century and a formidable amount of scholarship, from the I93os to the present day, has elucidated the connection between the rhetoric of liberty and the so-called investiture dispute..$^{50}$ Thus the term was not invented in its territorial sense before the Conquest.

\footnotetext{
Alfred P. Smyth (Basingstoke, I998), 85-102; Charles T. Wood, 'Fraud and its Consequences: Savaric of Bath and the Reform of Glastonbury', in The Archaeology and History of Glastonbury Abbey: Essays in Honour of the Ninetieth Birthday of C. A. Ralegh Radford, ed. Lesley Abrams and James P. Carley (Woodbridge, r99i), 273-83.

${ }^{4}$ As n. 24 .

${ }^{49}$ Patrick Wormald, 'Lordship and Justice in the Early English Kingdom: Oswaldslow Revisited', in Property and Power in the Early Middle Ages, ed. Wendy Davies and Paul Fouracre (Cambridge, I995), I I4-36, I28-9, reprinted in his Legal Culture, 326.

${ }^{50}$ Hans Hirsch, 'The Constitutional History of the Reformed Monasteries during the Investiture Contest', in Medieval Germany 9II-I250: Essays by German Historians, ed. and trans. G. Barraclough (2 vols., Oxford, I938), II, I31-73; Gerd Tellenbach, Libertas, Kirche und Weltordnung im Zeitalter des Investiturstreites (Stuttgart, 1936) (Church, State and Christian Society at the Time of the Investiture Contest, trans. R. F. Bennett (Oxford 1940), I-37); Rudolf Schieffer, 'Freiheit der Kirche: vom 9. zum II. Jahrhundert', Die Abendländische Freiheit vom Io zum ${ }_{4} 4$ Fahrhundert, ed. J. Fried (Sigmaringen, I99I), 49-66. See also H. E. J. Cowdrey, The Cluniacs and the Gregorian Reform (Oxford, 1970), 3-43, and his Pope Gregory VII, 1073-8 (Oxford, I998), $536-9$ (I owe this last reference to Dr Hamilton).
} 
I have no quibble with any of these arguments. The post-Conquest history of Anglo-Saxon liberty is indeed a history of impossible expectation - no historical precedent could support all or indeed any of the claims which succeeding generations chose to base on the notion of Anglo-Saxon liberty. It is a little heralded fact, however, that the forged claims to extravagant exemptions made by post-Conquest draftsmen present only one side of the story. Critics have been overzealous in their attempt to extirpate libertas from the pre-Conquest record. They have given inadequate attention to the fact that libertas, before its militant reinvention in the eleventh century at the hands of Gregorian reformers, had an earlier history. From the letters of Paul, through the writings of the church fathers, libertas had a secure place in Christian rhetoric ${ }^{51}$ and, although lodged in the body of texts inherited from the late Empire, the rhetoric of liberty escaped into active use, deployed in Carolingian synods of the ninth century, known and used by contemporary English draftsmen, and only later seized upon by post-Conquest forgers. Libertas before the end of the first millennium did not mean what later monastic propagandists took it to mean - full-scale exemption from episcopal and perhaps royal interference. It had a life of its own and its presence in the documentary record of England before the Norman Conquest puts a different complexion on the received view both of pre-Conquest diplomatic and the use and nature of Anglo-Saxon precedent in the later Middle Ages.

The remainder of this essay is concerned with the use and meaning of libertas before the Norman Conquest. I shall base my arguments on a distinct subset of pre-Conquest documents defined not by authenticity but by date: all survive in pre-Conquest form. This necessarily excludes a substantial body of evidence believed to be authentic but surviving only in later copy but the sacrifice is necessary in order to be clear about the nature of pre-Conquest tradition.

\section{Before the Conquest}

Michael Clanchy once memorably likened an early medieval archive to an old lady's handbag, filled with objects of diverse character and significance, each betokening something important to the owner..$^{5^{2}}$ If so, a continental churchman inspecting the archives of certain pre-Conquest monasteries after the Norman Conquest might well have been struck by

${ }^{51}$ Willy Szaivert, 'Die Entstehung und Entwickling der Klosterexemtion bis zum Ausgang des Ir. Jahrhunderts', Mitteilingen des Institutes für Österreicheische Geschichtsforschung, 59 (I95I), $265-98$.

$5^{2}$ M. T. Clanchy, From Memory to Written Record: England Io66-I307, 2nd edn (Oxford, I993), I56. His analogy captured the physical diversity of archives, objects as well as texts, but the same heterogeneity applies to the texts themselves. 
the wealth and also the eccentricity of the old lady in question. He would have found written title to estates and privilege, perhaps of considerable value; he might have been disappointed not to find claims to exemption (immunitas) as seen on the Continent ${ }^{53}$ (immunitas is a phrase all but confined to post-Conquest forgery, indeed almost symptomatic of it); but he might instead have found claims of a less defined but more ideological sort, claims to liberty. Such claims appear to have been relatively rare in continental diplomatic. Benoit-Michel Tock, in a preliminary survey of the language of French and Belgian charters published in 1997, compiled frequency-tables of the use of diplomatic terms. Libertas hardly registers before the eleventh century. ${ }^{54}$ But look across the channel and liberty is emblazoned across the English written record of the ninth, tenth and early eleventh centuries, not just in post-Conquest forgeries but in documents certainly copied before the Norman Conquest. Some i5 per cent of original pre-Conquest charters deployed the rhetoric of liberty in some form and the percentage rises further if we extend the field to authentic and spurious charters which survive as pre-Conquest copies..$^{55}$

Moreover, this body of documentation offered rich pickings to scavengers in search of documentary proof of the status of the churches of newly conquered England: grants of liberty, privileges of liberty, grants of liberty made by earlier benefactors, and not just liberty but ecclesiastical liberty, ecclesiastica libertas, libertas ecclesiarum, even the Gregorian formulation libertas ecclesiae. The abbey of Abingdon, for example, possessed a privilege of liberty, libertatis privilegium, whose surviving record, copied at or near 993 when King Æthelred had granted the charter, includes no fewer than fifteen references to libertas, including one to 'the liberty of the sacred monastery of Abingdon': sacri Ebbbandunensis coenobii libertatem. ${ }^{6}$ Worcester, too, possessed riches. ${ }^{57}$ No fewer than thirty-nine charters surviving in pre-Conquest form, a significant fraction of the pre-Conquest archive, in which the elusive libertas is associated with Anglo-Saxon donations, most notably in the early eleventh-century cartulary associated with Wulfstan, bishop of Worcester 1002-16, archbishop of York I002-23. Here again

${ }^{53}$ Emile Lesne, Histoire de la propriété ecclésiastique en France, I (Paris, I910), 260-78; E. Magnou-Nortier, 'Etude sur le privilège d'immunité du iv ${ }^{\mathrm{e}}$ au ix ${ }^{\mathrm{e}}$ siècle', Revue Mabillon, 6o (1984), 465-512; Barbara H. Rosenwein, Negotiating Space: Power, Restraint, and Privileges of Immunity in Early Medieval Europe (Manchester, 1999).

${ }^{54}$ Benoît-Michel Tock, 'Les mutations du vocabulaire latin des chartes au xie siècle', Bibliothèque de l'Ecole des Chartes, I55 (1997), II9-48.

${ }^{55}$ See Appendix, tables I and 2.

${ }^{56} \mathrm{~S} 876$, Charters of Abingdon Abbey, Part 2, ed. S. E. Kelly, Anglo-Saxon Charters VIII (Oxford, 200I), no. I24. Discussed by Alan Thacker, 'Æthelwold and Abingdon', Bishop Ethelwold: His Career and Influence, ed. Barbara Yorke (Woodbridge, I988), 43-64, at 53-4.

${ }^{57}$ On the Worcester charters see most recently Francesca Tinti, 'From Episcopal Conception to Monastic Compilation: Hemming's Cartulary in Context', Early Medieval Europe, II.3 (2002), 233-6I. 
we find rhetoric pregnant with significance for later readers: a 'privilege of liberty' dated 78I in which Offa, the great king of Mercia, is recorded as giving land to St Peter's Worcester 'for the use of ecclesiastical liberty', alongside other eighth-century gifts for the use of ecclesiastical liberty in usus/ius ecclesiasticae libertatis. ${ }^{8}$ With raw material like this post-Conquest churchmen hardly faced an imaginative leap in claiming for their churches pristine liberty: in confecting statements of ancient privilege they were defining and extending rights licensed in part by the pre-Conquest record.

Proof of the connection comes from the reuse of pre-Conquest documents - their copying, expansion, improvement..$^{59}$ This is not the place to attempt to demonstrate the process in detail, except to note one fact. Of the six English monasteries founded before the Norman Conquest which acquired exceptional legal privilege in the twelfth century, a process intimately connected with the fabrication of preConquest documentation, all but one laid claim to early documents which deploy the rhetoric of liberty. ${ }^{60}$ Two possessed charters which made mention of liberty, a further two possessed tenth- and eleventh-century single sheets which described early grants of libertas made by King Offa, and the fifth possessed an apparently authentic charter mentioning libertas for which no early copy survives. ${ }^{61}$

This raises a series of further questions: when, where and how did the term liberty enter the documentary record? Furthermore, given that later monastic draftsmen and historians often misconstrued the notion of liberty in the pre-Conquest period, what did libertas in its pre-Conquest guise actually mean? We will begin with the second question. Libertas, as used in these pre-Conquest charters, appears not to convey a single meaning, let alone a precise one. Aesthetic and rhetorical judgements as much as technical considerations appear often to have lain behind its deployment. The word occurs in relatively unstructured documents dispute settlements, exchanges, leases initiated by bishops as well as kings, synodal agreements, even private charters, in places where draftsmen had

${ }^{5^{8}} \mathrm{~S}$ I20: 'priuilegium libertatis,' 'ad utilitatem ecclesiasticae libertatis'. See also $\mathrm{S} 59$, I39, I73, I90.

${ }^{59}$ For an example see Simon Keynes, 'The Reconstruction of a Burnt Cottonian Manuscript: The Case of Cotton MS. Otho A. I', British Library fournal, 22.2 (1996), II3-60, at I 45 nn. 30-I . See also Crick, 'Liberty', and Charters of St Albans, ed. J. Crick, Anglo-Saxon Charters (Oxford, forthcoming), nos. I-3.

${ }^{60}$ Christopher Cheney listed as 'totally exempt from episcopal jurisdiction', St Augustine's, Canterbury, Westminster, Bury St Edmunds, St Albans, Evesham and Malmesbury: Episcopal Visitation of Monasteries in the Thirteenth Century, 2nd edn (Manchester, I983), 39 .

${ }^{61}$ St Augustine's Canterbury S 20 (s. xiii copy of extant s. ix single sheet preserved at Christ Church); Evesham S 495 s. x; Westminster S 67o, S I450 s. x; St Albans S 916 s. xi; Malmesbury $\mathrm{S}_{3} 63$ s. xii. 
more freedom of expression than in the more disciplined framework of a royal charter. ${ }^{62}$ Furthermore, when it occurs in Anglo-Saxon charters, libertas is a term used very informally indeed, apparently with no precise technical or diplomatic terms of reference. ${ }^{63}$ It is used in two particular contexts: either to describe a bundle of rights granted in a charter or to denote the charter itself. Libertas in this second sense occurs reasonably regularly in ninth- and tenth-century originals. ${ }^{64}$ Liberty has come to stand for little more than a grant. ${ }^{65}$ The first meaning - liberty as a bundle of rights - is less straightforward. ${ }^{66}$ The nature of the libertas thereby conceded is rarely explained, except in general terms, but to judge from context it takes one of two sorts. Libertas can mean an active right, freedom to do something, usually to bequeath. ${ }^{67}$ More commonly, however, liberty worked negatively. In the rhetoric of the Peasants' Revolt liberty came to represent a negation of the usual burdens and expectations attached to the possession of land. ${ }^{68}$ Half a millennium earlier, it seems, liberty served a similar purpose, it denoted freedom from normal worldly dues and royal exaction, all that is, except for the rights reserved to the king, the so-called common burdens of bridgework, army duty and fortress work. ${ }^{69}$ To a beneficiary before the Norman Conquest, therefore,

\footnotetext{
${ }^{62}$ See further Crick, 'Liberty', 97-8.
}

${ }^{63}$ It can appear in almost any part of a charter in the granting clause, in the statement of powers, in the immunity clause, in the anathema, the royal attestation, in endorsements.

${ }^{64}$ In three mid-ninth-century single sheets surviving as apparent originals, a libertas is confirmed or written, whether so described in the attestations, endorsement or in the main text of the charter (Appendix: table I, S I9o, I270, 338). For example, in a grant to Worcester of 836 Wiglaf, king of Mercia is made to declare 'hanc libertatem scripsi et scribere precipi [sic]' and the contemporary endorsement describes the document as 'סes friodom' (S I270).

${ }_{5}$ Much like the usage of immunitas on the Continent: Rosenwein, Negotiating Space, 3 .

${ }^{66}$ In a private charter of 875 (S I203), copied by Christ Church scribe, the lay donor is made to grant land to Wighelm in return for 120 mancuses of gold 'cum eadem libertate quam Ælfredus rex Occidentalium Saxonum necnon æt Cantwariorum mihi in ius proprium ... donauit'.

${ }_{7}^{67}$ Thus $\mathrm{S}_{40}$ 'Potestas quoque ipsi datur ut in libertate terram habeat quamdiu uiuat et postea cuicumque hominum uoluerit in aeternam libertatem derelinquat' or S 89o 'in eadem libertate relinquiendi licentiam habeat'.

68 '[Libertas] did metaphorical duty for abolition of all the oppressions under which the countryside labored', Justice, Writing and Rebellion, 45 also 36.

${ }^{69}$ For example, 'Sit autem predictum rus perpetuali libertate liber ab omni mundiali censu et regali coactione excepto communi labere expeditione pontis arcisue coedificatione' S 470 (AD 940). On the nature of these burdens see N. P. Brooks, 'The Development of Military Obligations in Eighth- and Ninth-Century England', England before the Conquest: Studies in Primary Sources Presented to Dorothy Whitelock, ed. Peter Clemoes and Kathleen Hughes (Cambridge, I97I), 69-84, reprinted in his Communities and Warfare 700-I400 (2000), 32-47; Richard P. Abels, Lordship and Military Obligation in Anglo-Saxon England (1988), 43-57; Rosamond Faith, The English Peasantry and the Growth of Lordship (Leicester, I997), 94-9. Exemption from the common burdens and/or general statements of freedom from royal dues occurs very commonly in single sheets mentioning libertas. 
a grant of libertas had a familiar function; it suspended a designated area of land from normal expectations, from royal obligations, from anticipated routes of transmission..$^{70}$ The details of the process elude description, the burdens from which the lucky recipient has been spared are never dwelt on and perhaps varied over time (the beauty of the unwritten), but in all circumstances, the outcome was plain enough. Thus libertas is a precious commodity. When land changed hands owners were permitted to ensure that it passed with any special freedom granted in the past. ${ }^{71}$ Libertas thus represents the Latinising of a peculiarly home-grown practice, the releasing of land from unwritten obligations. Libertas is effectively the quality bestowed when land is booked..$^{72}$

Further demonstration of the ease with which libertas can be situated within the vocabularies of English draftsmen before the Norman Conquest comes from consideration of related terms. Far from being an anachronism or foreign intrusion, libertas fits comfortably into preConquest diplomatic as part of a vocabulary of the freeing of land whose other components have attracted relatively little notice. Latin cognates of libertas serve as verbs, adjectives and adverbs to describe grants, ${ }^{73}$ and a penumbra of vernacular terms can be identified. In his recent study of slavery in early medieval England, David Pelteret identified from a range of sources, narrative and documentary, twenty-three words, mostly vernacular, which describe the giving of land in terms of subjection and liberation. ${ }^{74}$ Some of the compounds which he lists, such as sundorfreodom (a special right over land) and freolsboc (which he translates as 'a land charter granting superiority over land, with freedom from the jurisdiction of others'), fall outside the limits of the present study: they do not occur in documents surviving in pre-Conquest form. Certain of his terms do, however. Freo-dom and freols, for example, surely direct OE equivalents of libertas, mirror Latin usage strikingly closely and are attested in documents copied in the ninth, tenth and eleventh centuries. ${ }^{75}$ Freodom has six meanings in Pelteret's list. ${ }^{76}$ The first, which can be summarised as personal freedom, is the liberty associated with the Anglo-Saxons by post-medieval writers. The last two provide direct translations of libertas

\footnotetext{
${ }^{70}$ For examples of the range of possible obligations on land see Faith, The English Peasantry, $89-105$.

${ }^{71} \mathrm{~S}_{40}$, 1264, 890. Above, nn. 66-7.

${ }^{72}$ On this term see, for example, Susan Reynolds, 'Bookland, Folkland and Fiefs', AngloNorman Studies, I4 (I99I [1992]), 2I I-27, esp. 216-17.

${ }^{73}$ Libero, liber, libere. For their use in early documents see, for example, $\mathrm{S}_{3} \mathrm{I}$ (copied before 80o) and $\mathrm{S}_{4 \mathrm{I}}\left(\mathrm{AD} 805^{-7}\right)$.

${ }^{74}$ David A. E. Pelteret, Slavery in Early Mediaeval England from the Reign of Alfred until the Twelfth Century (Woodbridge, 1995), 47-8, 276-8, 283-4, 303-4.

${ }^{75}$ Listed below, Appendix, table 3.

${ }^{76}$ Pelteret, Slavery, $276-8$.
} 
as it is used in pre-Conquest Latin charters: 'freedom to exercise rights without being subject to the control of another', 'a charter granting rights over property'. ${ }^{77}$ Freols, another term employed in documents copied before the Norman Conquest, shows a range of meanings extending in identical fashion from the general to the particular, from personal and fiscal freedom to the document itself. ${ }^{7}$

Pelteret's discussion helps us round a conceptual difficulty. Liberty is not a word bandied about by many of the current generation of Anglo-Saxon historians - reciprocity, conspicuous consumption, slavery, certainly, but not liberty. Liberty, after all, is a very classical notion. As an abstraction its origins are Greek (eleutheria). As a working concept, it is Roman, developed within a state with a territorial mentality: boundaries, controls, law. It appears in this sense in the New Testament, especially in the letters of Paul which supply a quarter of all references to the word in the Vulgate concordance $; 9$ indeed, the Christian notion of freedom links the antique to the Anglo-Saxon particularly fruitfully. For the church fathers, as for other citizens of the Roman Empire, freedom did not operate in a vacuum; freedom could only be understood in relation to something else. Thus freedom and service are often paired..$^{80}$ Understood in relation to slavery, so much more familiar an aspect of the AngloSaxon social and political landscape, liberty looks less like an exile from an alien cultural environment, and more like a term assimilable to a post-Roman milieu. By focusing not on liberty, but slavery (the same servitude-freedom pairing as in Christian writing), we gain a fresh light on libertas. Draftsmen in Anglo-Saxon England in the years around $\mathrm{AD} 800$ described the conveyance of land in written form in all its complexity using a metaphor drawn from Christian tradition: freedom. Modern historians have adopted a different vocabulary for the granting of land by charter. Following a parallel metaphor used by certain AngloSaxon draftsmen at approximately the same date, they describe the charter in terms of literate record: the book. ${ }^{8 \mathrm{r}}$

This brings us to the final question about the arrival of the rhetoric of freedom in the apparently alien environment of pre-Conquest England. How did it get there? As I have already suggested, there is a case for regarding the appearance of libertas as a rhetorical strategy, a word chosen

77 Definitions 2-3 concern spiritual freedom; the fourth entails 'Freedom from dues payable to an overlord': ibid., 276-7.

$7^{8}$ Pelteret, Slavery, 282-3.

${ }^{79}$ Seven of twenty-six references.

${ }^{80}$ Tellenbach, Church, State and Christian Society, 2-Io.

${ }^{81}$ Eric John identified the first reference to the charter as book in a document of AD 798 (S I53): Orbis Britanniae and Other Studies (Leicester, I966), 74. On the etymology of the term see D. H. Green, Medieval Listening and Reading: The Primary Reception of German Literature 80o-I300 (Cambridge, I994), 37. 
by certain draftsmen to express something for which draftsmen elsewhere found a different word or words. In these circumstances the time and place of the deployment of the language of liberty become significant. We have touched on two important episodes in this history already. Numerous references to liberty adorn the Worcester cartulary, a collection compiled and copied in the early eleventh century and associated with Archbishop Wulfstan, homilist and canonist. A generation before, strong statements about ecclesiastical liberty had issued from the newly reformed Benedictine abbey of Abingdon, an institution invigorated by contact with the motors of ecclesiastical reform on the Continent and under the direction of Bishop Æthelwold, a man portrayed by his tenthcentury biographer granting privileges of liberty in gold letters. ${ }^{82}$ Both at Worcester and at Abingdon these reformers were inspired by proximity to sites of particular religious authority where libertas-rhetoric was deployed, one historical, the other contemporary: Wulfstan through his exposure to canonical texts, Æthelwold through contact with Cluniac monasticism and the return to canonical values. ${ }^{83}$ The libertas-tradition latent in Christian writing periodically manifested itself.

Another such episode predates the examples just examined by early two centuries. The rhetoric of liberty begins to flow from the pens of English draftsmen in strength from the turn of the ninth century but starting as a trickle in the middle of the eighth. The circumstances are instructive. Like the Frankish empire of Charles Martel, created in the second quarter of the eighth century using monastic lands and the control of ecclesiastical appointments, the Mercian hegemony constructed at approximately the same time across the channel was built on very selective respect for ecclesiastical power. Offa's creation of a third archiepiscopal see, at Lichfield, in 787 is the boldest example, which allowed him to override and ultimately to stifle the archbishop of Canterbury, at least for a while, but there are plenty of other manifestations of open competition between ecclesiastical privilege and royal prerogative, from the synod of Gumley in 749 to Archbishop Wulfred's war with Coenwulf of Mercia and his successors over domination of the Kentish monasteries, fought in the $8 \mathrm{I}$ os and 820 s. $^{84} \mathrm{It}$ is perhaps not surprising to witness the deployment of the language of liberty by the church in these circumstances. According

\footnotetext{
${ }^{82}$ Wulfstan of Winchester: The Life of St Athelwold, ch. 21, ed. Michael Lapidge and Michael Winterbottom (Oxford, I99I), 36-7. Cited by Kelly, Charters of Abingdon, xli.

${ }^{83}$ For Æthelwold's Cluniac context see Patrick Wormald, 'Ethelwold and his Continental Counterparts: Contact, Comparison, Contrast', in Bishop Ethelwold: His Career and Influence, ed. Barbara Yorke (Woodbridge, I988), I3-42. See also Crick, 'Liberty', Ioo-I.

${ }^{8}$ See Nicholas Brooks, The Early History of the Church of Canterbury: Christ Church from 597 to 1066 (Leicester, I984), I32-43; Simon D. Keynes, The Councils of Clofesho, IIth Brixworth Lecture (Leicester, 1994); Catherine Cubitt, Anglo-Saxon Church Councils c. 650-c. 850 (Leicester, I995), 218-22.
} 
to the manuscript-evidence, the earliest datable reference to libertas in the Anglo-Saxon written record comes from the synod of Gumley. ${ }^{85}$ The first significant concentration of documents deploying the rhetoric of liberty come from the pontificate of Wulfred.

Archbishop of Canterbury for nearly thirty years, from 805 to 832 , Wulfred presided over the see of Canterbury during the reigns of four Mercian kings and subsequently survived the transition from Mercian to West Saxon control. Nicholas Brooks tells us that his wheelings and dealings transformed the landed wealth of the church at Canterbury, but he is perhaps best remembered for his ability to fight three successive Mercian kings in a series of acrimonious disputes over royal domination of the Kentish church which lasted fifteen years, caused him to be deprived of his office at some point before 822 and was only settled in $826 .{ }^{86} \mathrm{~A}$ great deal of evidence points to a connection between Wulfred and the language of liberty. More charters mentioning libertas may be associated with him than with any other figure. He was donor, beneficiary, his scribes copied them, he has even been credited with copying one and forging another. ${ }^{87}$ The rhetoric of libertas is even deployed in a number of forgeries linked with Wulfred on the grounds that they 'seem to bear on [his] claim to the lordship of Reculver and Minster-in-Thanet', in other words the dispute which caused strife with successive Mercian kings between 817 and $826 .^{88}$ The occurrences of libertas in these charters concern little more abstract than the granting of land, but it is significant that this archbishop's draftsmen should have begun to describe bookland in these terms.

Wulfred inhabited an environment in which liberty was being actively deployed. His Carolingian counterparts took measures to protect clerical and episcopal libertas in a series of important synods in the second quarter of the ninth century: Council of Paris 829, Aachen 836, Quierzy 858. ${ }^{89}$ Already, by 803, similar notions had reached Canterbury. Eðelheard, Wulfred's predecessor, exhorted the monasteries 'which have once been

\footnotetext{
${ }^{85} \mathrm{~S}$ 92. On the manuscript see Keynes, 'The Reconstruction', and Cubitt, Anglo-Saxon Church Councils, 266-7.

${ }^{86}$ Brooks, The Early History, I34, I80-3.

${ }^{87}$ See below, Appendix, tables I-2. As donor and beneficiary: S 40, 4I, I264, I69, I77, I68, I266, I436, I88. S 90 (copy), S 22 (forgery); see below, n. 88.

${ }^{88}$ Brooks, The Early History, I9I. Brooks, without reference to the libertas connection, linked three charters with Wulfred on quite different grounds: two privileges concocted, so Brooks suggested, at Christ Church during Wulfred's pontificate $\left(\mathrm{S}_{22}, 9 \mathrm{o}\right)$ and records of synods of Clofesho of 824 and 825 , one of which (S I436) contains references to grants of libertas: The Early History, I9I-7. Below, Appendix, tables I-2.

${ }^{89}$ Concilia aevi Karolini I. II, ed. A. Werminghoff, Monumenta Germaniae Historica [hereafter MGH] Concilia II (Hannover, 1908), 669, 680, 721; Die Konzilien der karolingingischen Teilreiche $843-859$, ed. Wilfried Hartman, MGH Concilia III, Concilia aevi Karolini DCCXLIII-DCGCLIX (Hannover, I984), 4I3. See also the discussion by Schieffer, 'Freiheit der Kirche', 6o.
} 
dedicated to Christ, the Lord, by faithful men in perpetual liberty perpetuam in libertatem' to reject lay lordship and look to the monastic life. ${ }^{\circ}$ He made the plea at a synod at Clofesho acting on the authority of a 'mandate' of Leo III which he had brought back from Rome, shortly after the restoration of his own metropolitan authority by the same pope. ${ }^{91}$ Comparable claims had been made at Worcester half a century earlier. There, as at Canterbury, libertas first occurs in charters which appear to offer a response to the aggression of Mercian kings, although the word is not used in the Æthelheardian sense to defend monasteries in general, but rather the privileges exercised on their estates. Brooks noted a series of eighth- and ninth-century charters in which the bishops of Worcester took monasteries directly into their own lordship, five of which include references to libertas. ${ }^{92}$ Such charters would have served to preempt royal control.

The first evidence for the use of the language of liberty in AngloSaxon charters comes from the Mercian supremacy, but less clear is the precise nature of the source. Continental tradition does not supply an immediate explanation: neither the Rule of Chrodegang, nor that of Benedict, nor Carolingian diplomatic provide direct analogies for the Anglo-Saxon use of libertas. ${ }^{93}$ That draftsmen operating in eighthcentury England encountered and deployed the word need occasion no surprise, however. The central texts of Christianity, the New Testament, the patristic and canonical writings of the church in the former Roman Empire offered a natural medium for the flow of Roman ideas to the remote West. Any number of channels might have served, each of them accessible directly or through intermediate sources throughout the preConquest period. Augustine, Gregory, Jerome, Cassian and other late antique writers used the term libertas freely and their writings stocked the libraries of early England. ${ }^{94}$ Texts known at the Canterbury school as early as the late seventh century include at least one which deployed the

$9^{\circ}$ The apparently contemporary single sheet S I43rb; see Brooks, Early History, I79 and n. I6 (his translation).

${ }^{91}$ Papal influence is palpable, too, in the Carolingian councils: Concilia aevi Karolini I. II, ed. Werminghoff, 605 .

${ }^{92}$ Brooks, Early History, I79-80 and n. I7: S I255, I257, I39, 207, I72, I46, II87.

${ }^{93}$ Libertas, where it occurs in Carolingian charters, usually means personal freedom, manumission. It occasionally denotes the freedom of monastic houses but it pertains to the community rather than its estates. Thus the libertates mentioned have a meaning closer to the post-Conquest: see Wilhelm Schwarz, 'Jurisdicio und Condicio: eine Untersuching zu den Privilegia libertatis der Klöster', Zeitschrift der Savigny-Stiftung für Rechtsgeschichte, K. A. 76 (I959), 34-98.

94 The Patrologia Latina database reveals multiple examples of use of libertas, particularly by patristic writers (Jerome, Ambrose, Augustine, Gregory, Orosius especially) and later by Carolingian authors (Rhabanus Maurus, Smaragdus). John Cassian used the term with some frequency, but usually in the Pauline sense of libertas arbitrii-free will. 
rhetoric extensively. ${ }^{95}$ Libertas occasionally appears in the canons, most particularly those of the Council of Carthage of $525 \cdot{ }^{96}$ Potentially, at least, the papacy operated as channel for the passing of Roman terminology and concepts to the unRoman parts of the West. The term libertas could be synonymous with papal privilege in Old English and Latin, and contact with the papacy often preceded or was identified with the rhetoric of liberty ${ }^{97}$ Proximity to Romanitas brought exposure to notions of liberty.

\section{Conclusions}

The pre-modern story of Anglo-Saxon liberty as presented here divides into three: the pre-Conquest, the closely post-Conquest and the postReformation. Modern commentators attempting to understand property transfer in England before the Norman Conquest will recognise the divisions; they necessarily find their vision clouded by the copying and rewriting to which the pre-Conquest documentary record was subjected at these times. Indeed, it was in an effort to dispel some of the cloud that the tradition of pre-Conquest liberty was rejected altogether. As is well recognised, libertas constituted a goal to which forgers aspired in the middle period. Libertas, to them, carried expectations of well-defined freedoms. New life was breathed into the medieval traditions after the Middle Ages, by institutional heirs seeking precedent for rights apparently sanctioned by ancient charter. Just as constitutional rights were pressed back to English antiquity, institutional claims followed a similar trajectory; the textual remnants of the middle period could be pressed into service again. But postConquest and post-Reformation invocation of pre-Conquest precedent cannot be understood without reference to the first period, when an earlier rhetorical tradition flourished, different from what followed in scope and aim, but not unconnected with it. As we have seen, libertas already belonged in the written record before the Norman Conquest, a fact demonstrated by the physical evidence, authentic and inauthentic texts surviving in pre-Conquest form, and by the existence of an entire vocabulary of liberation associated with the granting of land by charter. Its presence there serves to remind us of well-known facts: the inescapable hold which late antique thought and writing exercised over nascent English Latinity and learning, and the hybridity and eclecticism of the English legal

\footnotetext{
${ }^{95}$ Michael Lapidge, 'The School of Theodore and Hadrian', Anglo-Saxon England, I5 (I986), 45-72, at 54-5. Orosius's Historiae aduersum paganos is the text in question.

${ }_{96}^{6}$ Concilia Africae A. $345^{-A} .525$, ed. C. Munier, Corpus Christianorum Series Latina CCLIX (Turnhout, 1974), 255-82, for example, 255-6, 274, 276, 279-80; see also Council of Carthage of $\mathrm{AD} 345^{-8}$, ibid., $3^{-\mathrm{IO}}$. I have not been able to plot a definitive connection between these canons and any of the main outbreaks of libertas-rhetoric before the Conquest.

${ }^{97}$ See, for example, Pelteret, Slavery, 303-4; Brooks, I33-4; Wilhelm Levison, England and the Continent in the Eighth Century (Oxford, I946), I8-33; also above, nn. 90-I.
} 
tradition, a body of learning indebted to the canons and to Christian thought in general, and hardly yet launched as a technical discourse..$^{8}$

This brings us to another constant in this discussion: the written word. In the same way that the tradition of English constitutional liberties hangs on a chain of textual authority, however tenuously, leading back to Magna Carta and before, the notion of institutional liberties was authorised by the written record. ${ }^{99}$ The monastic researchers with whom some of this essay has been concerned, the draftsmen and historians responsible for the wholesale adaptation of the written record after the Norman Conquest did not conjure the rhetoric of monastic liberty out of thin air. ${ }^{100}$ They elaborated, interpreted and extended a form of discourse deployed in the written record which they had inherited. We should not be surprised at the wilfulness of their interpretation. Brian Tierney noticed a certain 'creative misunderstanding' in medieval jurists' attempts to interpret notions of freedom which they found in texts from late antiquity, from an environment so alien to the one which they knew that much was lost in the process of translation across time. ${ }^{\text {IOI }}$ Adaptation of textual authority is a marked feature of the story of Anglo-Saxon liberty. Liberty was invoked partly because it was licensed by written authority, whether that authority resided in the prescriptive texts of the Christian religion, as used by English churchmen in the eighth and ninth centuries, or whether it was contained in archival material rewritten after the Conquest or rediscovered after the Reformation. ${ }^{102}$ Behind the so-called 'bogus' charters stands not a perversion of the written record but an inuentio in the medieval sense: a finding. This was no crude anachronism and blindness to the past but a movement ad fontes, an appropriation of the written record certainly, and one undertaken in a polemical spirit, but a return to the past of the sort which perhaps inspired the adoption of the libertas rhetoric in the first place and which, in later centuries, would lead other churchmen to seek to recreate the Anglo-Saxon past in the spirit of reformation.

${ }^{98}$ Wormald, The Making of English Law, I, esp. 4I6-29. Note, too, the comments of Martin Brett, 'Theodore and the Latin Canon Law', Archbishop Theodore: Commemorative Studies on his Life and Influence (Cambridge, I995), I20-40, at I37. On the underlying intellectual problems see Vivien Law, The History of Linguistics in Europe from Plato to I6oo (Cambridge, 2003), I24-6.

${ }^{99}$ Above, nn. 4, II.

${ }^{100} \mathrm{On}$ the process of reinvention of the written record after the Conquest see Bruce O'Brien, 'Forgery and the Literacy of the Early Common Law', Albion, 27.I (I995), I-I8. On 'exemplifications' from Domesday Book see Faith, 'The "Great Rumour", and on the search for precedent in the Middle Ages see Susan Reynolds, 'Magna Carta I297 and the Legal Use of Literacy', Historical Research, 62 (I989), 233-44 at 235.

${ }^{101}$ See above, n. Io.

${ }^{102}$ This history thus does not obey generalisations about medieval communication suggested by some early modernists: see, for example, Woolf, Social Circulation, in, Adam Fox 'Custom, Memory and the Authority of Writing', in The Experience of Authority in Early Modern England, ed. Paul Griffiths, Adam Fox and Steve Hindle (Basingstoke, I996), 89-i 6 at i Io. 
LIBERTY AND THE ANGLO-SAXONS REVISITED

\section{APPENDIX: THE LANGUAGE OF LIBERTY IN GHARTERS BEFORE THE NORMAN CONQUEST}

Table I Charters surviving in arguably contemporary form which make reference to libertas.

\begin{tabular}{|c|c|c|c|}
\hline $\begin{array}{l}\text { Date of } \\
\text { transaction }\end{array}$ & Reference & Archive & Additional comments \\
\hline 749 & $\mathrm{~S} 92$ & Worcester & $\begin{array}{l}\text { Grant of privileges to Mercian } \\
\text { churches }\end{array}$ \\
\hline 770 & $\mathrm{~S}_{59}$ & Worcester & \\
\hline 785 & $\mathrm{~S}_{123}$ & Christ Church, Canterbury & \\
\hline $793 \times 79^{6}$ & $\mathrm{~S}_{\text {I39 }}$ & Worcester & \\
\hline 801 & $\mathrm{~S}_{\text {г }} 86 \mathrm{a}$ & Christ Church, Canterbury & \\
\hline 803 & $\mathrm{~S}_{\text {I443 }} \mathrm{Ib}$ & Christ Church, Canterbury & Synod of Clofesho \\
\hline 805 & S I259 & Christ Church, Canterbury & Restoration secured by Æthelheard \\
\hline 805 & $\mathrm{~S}_{40}$ & Christ Church, Canterbury & Archbishop Wulfred as beneficiary \\
\hline $805 \times 807$ & $\mathrm{~S}_{4 \mathrm{I}}$ & Christ Church, Canterbury & Archbishop Wulfred \\
\hline $8 \mathrm{II}$ & $\mathrm{S}_{\mathrm{I}} 68$ & Christ Church, Canterbury & Archbishop Wulfred as beneficiary \\
\hline 8II & $\mathrm{S}_{1264}$ & Christ Church, Canterbury & Archbishop Wulfred as grantor \\
\hline 812 & S I69 & Christ Church, Canterbury & Archbishop Wulfred as beneficiary \\
\hline $8 I 4$ & $\mathrm{~S}_{\mathrm{I} 73}$ & Worcester & \\
\hline $8 \mathrm{I} 4$ & $\mathrm{~S}_{177}$ & Christ Church, Canterbury & Archbishop Wulfred as beneficiary \\
\hline 824 & $\mathrm{~S}_{\text {I266 }}$ & Christ Church, Canterbury & Archbishop Wulfred as grantor \\
\hline $825[827]$ & $\mathrm{S}_{1436}$ & Christ Church, Canterbury & Archbishop Wulfred as party \\
\hline $8_{3} \mathrm{I}$ & S I88 & Christ Church, Canterbury & Archbishop Wulfred as party \\
\hline $8_{3} 6$ & $\mathrm{~S}$ igo & Worcester & \\
\hline $8_{3} 8$ & $\mathrm{~S}_{\mathrm{I} 43^{8}}$ & Christ Church, Canterbury & Dispute settlement \\
\hline $840 \times 852$ & $\mathrm{~S}$ I270 & ?Hereford & \\
\hline 843 & S 293 & Christ Church, Canterbury & \\
\hline 845 & $\mathrm{~S}$ II94 & Christ Church, Canterbury & \\
\hline 867 & $\mathrm{~S}_{33^{8}}$ & Christ Church, Canterbury & \\
\hline 875 & $\mathrm{~S}_{\mathrm{I} 2 \mathrm{O}}$ & Christ Church, Canterbury & \\
\hline $90 \mathrm{I}$ & $\mathrm{S}_{22 \mathrm{I}}$ & Much Wenlock & \\
\hline 903 & $\mathrm{~S}_{367}$ & Christ Church, Canterbury & \\
\hline 940 & $\mathrm{~S}_{470}$ & New Minster, Winchester & \\
\hline 944 & $\mathrm{~S}_{497}$ & Christ Church, Canterbury & \\
\hline 944 & $\mathrm{~S}_{495}$ & Evesham & \\
\hline 947 & $\mathrm{~S}_{528}$ & Christ Church, Canterbury & \\
\hline 960 & $\mathrm{~S} 687$ & Abingdon & \\
\hline 966 & $\mathrm{~S} 745$ & New Minster, Winchester & \\
\hline 974 & S 795 & Exeter & \\
\hline 987 & S 864 & Rochester & \\
\hline 995 & S 884 & Muchelney & \\
\hline 997 & S 890 & Exeter & \\
\hline $99^{8}$ & S 892 & Coventry & \\
\hline 1007 & S 9i6 & St Albans & Libertas associated with King Offa \\
\hline IOI9 & $\mathrm{S} 95^{6}$ & New Minster, Winchester & \\
\hline 1024 & S g6I & Abbotsbury & \\
\hline IO3I & $\mathrm{S}_{97 \mathrm{I}}$ & Exeter & \\
\hline 1042 & S 994 & Old Minster, Winchester & \\
\hline IO44 & $\mathrm{S}$ I003 & Exeter & \\
\hline
\end{tabular}


Table 2 Charters surviving as pre-Conquest copies which make reference to libertas.

\begin{tabular}{|c|c|c|c|c|}
\hline $\begin{array}{l}\text { Date of } \\
\text { copy }\end{array}$ & $\begin{array}{c}\text { Date of } \\
\text { transaction }\end{array}$ & Reference & Archive & Additional comments \\
\hline s. ix & 699 & $\mathrm{~S}_{20}$ & Christ Church, Canterbury & Privilege to Kentish churches \\
\hline s. $i x^{I}$ & 742 & S go & Christ Church, Canterbury & Privilege to Kentish churches \\
\hline s. $x^{2}$ & 955 & S 67I & Rochester & \\
\hline s. $x$ & 951 (?for 959) & $\mathrm{S}_{\mathrm{I}} 45^{\circ}$ & Westminster & Liberty associated with Offa \\
\hline s. $x$ & $95^{\mathrm{I}}$ & S 670 & Westminster & Liberty associated with Offa \\
\hline s. $\mathrm{x} / \mathrm{xi}$ & $95^{6}$ & $\mathrm{~S}_{587}$ & Abingdon & \\
\hline s. $x / x i$ & 680 (?for 685) & $\mathrm{S}_{230}$ & Christ Church, Canterbury & Spurious \\
\hline s. $x / x i$ & 993 & $\mathrm{~S} 876$ & Abingdon & \\
\hline s. $\mathrm{x} / \mathrm{xi}$ & 933 & $\mathrm{~S}_{42 \mathrm{I}}$ & Exeter & \\
\hline S. $x i^{1}$ & $699 \times 7 \mathrm{I} 6$ & $\mathrm{~S}_{22}$ & Christ Church, Canterbury & Privilege to Kentish churches \\
\hline s. $\mathrm{xi}^{\mathrm{I}}$ & 680 & $\mathrm{~S}_{52}$ & Worcester & Worcester cartulary \\
\hline s. $\mathrm{xi}^{\mathrm{I}}$ & $699 \times 704$ & S 64 & Worcester & Worcester cartulary \\
\hline s. $x i^{1}$ & 765 & $\mathrm{~S}_{107}$ & Worcester & Worcester cartulary \\
\hline s. $\mathrm{xi}^{\mathrm{I}}$ & 718 (?for 727 ) & $\mathrm{S} 84$ & Worcester & Worcester cartulary \\
\hline s. $\mathrm{xi}^{\mathrm{I}}$ & 766 & $\mathrm{~S}$ I92 & Worcester & Worcester cartulary \\
\hline s. $x i^{1}$ & 774 & $\mathrm{~S}_{\text {I255 }}$ & Worcester & Worcester cartulary \\
\hline s. $\mathrm{xi}^{\mathrm{I}}$ & $777 \times 779$ & $\mathrm{~S}_{\mathrm{I} 47}$ & Worcester & Worcester cartulary \\
\hline s. $\mathrm{xi}^{\mathrm{I}}$ & 780 & $\mathrm{~S}$ i 6 & Worcester & Worcester cartulary \\
\hline s. $x i^{I}$ & $78 \mathrm{I}$ & $\mathrm{S}_{120}$ & Worcester & Worcester cartulary \\
\hline s. $\mathrm{xi}^{\mathrm{I}}$ & $78 \mathrm{I}$ & $\mathrm{S}_{\mathrm{I} 2 \mathrm{I}}$ & Worcester & Worcester cartulary \\
\hline s. $\mathrm{xi}^{\mathrm{I}}$ & $78 \mathrm{I}$ & $\mathrm{S}_{\text {I257 }}$ & Worcester & Worcester cartulary \\
\hline s. $x i^{1}$ & $793 \times 79^{6}$ & $\mathrm{~S}_{14} 6$ & Worcester & Worcester cartulary \\
\hline s. $\mathrm{xi}^{\mathrm{I}}$ & 794 & $\mathrm{~S}_{137}$ & Worcester & Worcester cartulary \\
\hline S. $\mathrm{xi}^{\mathrm{I}}$ & 799 (?for 802) & $\mathrm{S}_{\text {I54 }}$ & Worcester & Worcester cartulary \\
\hline s. $x i^{I}$ & 804 & $\mathrm{~S}_{1187}$ & Worcester & Worcester cartulary \\
\hline s. $\mathrm{xi}^{\mathrm{I}}$ & $8 \mathrm{I}_{4}\left(\right.$ for $\left.8 \mathrm{I}_{3}\right)$ & $\mathrm{S}_{172}$ & Worcester & Worcester cartulary \\
\hline s. $\mathrm{xi}^{\mathrm{I}}$ & $8 \mathrm{I} 6$ & $\mathrm{~S}$ I80 & Worcester & Worcester cartulary \\
\hline s. $x i^{I}$ & 840 & $\mathrm{~S}_{\mathrm{I} 92}$ & Worcester & Worcester cartulary \\
\hline s. $\mathrm{xi}^{\mathrm{I}}$ & $84 \mathrm{I}($ for 840$)$ & S I93 & Worcester & Worcester cartulary \\
\hline s. $\mathrm{xi}^{\mathrm{I}}$ & $84 \mathrm{I}$ & $\mathrm{S}_{194}$ & Worcester & Worcester cartulary \\
\hline s. $x i^{1}$ & $84 \mathrm{I}($ for 840$)$ & $\mathrm{S}$ I96 & Worcester & Worcester cartulary \\
\hline s. $\mathrm{xi}^{\mathrm{I}}$ & 845 (for 844$)$ & $\mathrm{S}$ I98 & Worcester & Worcester cartulary \\
\hline s. $\mathrm{xi}^{\mathrm{I}}$ & 849 & S I99 & Worcester & Worcester cartulary \\
\hline s. $\mathrm{xi}^{\mathrm{I}}$ & 855 & $\mathrm{~S}_{206}$ & Worcester & Worcester cartulary \\
\hline s. $\mathrm{xi}^{\mathrm{I}}$ & 855 & $\mathrm{~S}_{207}$ & Worcester & Worcester cartulary \\
\hline s. $\mathrm{xi}^{\mathrm{I}}$ & 857 & $\mathrm{~S}_{208}$ & Worcester & Worcester cartulary \\
\hline s. $\mathrm{xi}^{\mathrm{I}}$ & 864 & $\mathrm{~S}_{21 \mathrm{O}}$ & Worcester & Worcester cartulary \\
\hline s. $\mathrm{xi}^{\mathrm{I}}$ & 875 & $\mathrm{~S}_{215}$ & Worcester & Worcester cartulary \\
\hline s. $\mathrm{xi}^{\mathrm{I}}$ & 880 [887] & $\mathrm{S}_{217}$ & Worcester & Worcester cartulary \\
\hline s. $\mathrm{xi}^{\mathrm{I}}$ & 889 & $\mathrm{~S}_{346}$ & Worcester & Worcester cartulary \\
\hline s. $x i^{1}$ & 929 & $\mathrm{~S}_{4 \mathrm{OI}}$ & Worcester & Worcester cartulary \\
\hline s. $x i^{I}$ & 929 & $\mathrm{~S}_{402}$ & Worcester & Worcester cartulary \\
\hline s. $x i^{1}$ & 934 & $\mathrm{~S}_{428}$ & Worcester & Worcester cartulary \\
\hline S. $x i^{I}$ & 962 & $\mathrm{~S}_{1298}$ & Worcester & Worcester cartulary \\
\hline ? s. $\mathrm{xi}^{\mathrm{I}}$ & 900 & $\mathrm{~S}_{360}$ & New Minster, Winchester & Imitative script \\
\hline ? s. $\mathrm{xi}^{\mathrm{I}}$ & $93^{8}$ & $\mathrm{~S}_{443}$ & Old Minster, Winchester & Imitative script \\
\hline ? s. $\mathrm{xi}^{\mathrm{I}}$ & $94^{8}$ & $\mathrm{~S}_{540}$ & Old Minster, Winchester & Imitative script \\
\hline
\end{tabular}


Table 3 Charters surviving in pre-Conquest form employing vernacular terms for libertas.

\begin{tabular}{|c|c|c|c|c|}
\hline $\begin{array}{l}\text { Date of } \\
\text { copy }\end{array}$ & $\begin{array}{c}\text { Date of } \\
\text { transaction }\end{array}$ & Reference & Archive & Vernacular term \\
\hline s. ix & $8_{3} 6$ & S igo & Christ Church, Canterbury & Friodom \\
\hline s. ix med. & $845 \times 853$ & $\mathrm{~S}_{\text {I5 }}$ IO & Christ Church, Canterbury & Friodom \\
\hline s. ix & 888 (?for 868 ) & $\mathrm{S}_{1204}$ & Christ Church, Canterbury & Friols \\
\hline s. $\mathrm{x}$ & $95^{8}$ & S I506 & Christ Church, Canterbury & Freodom \\
\hline s. $\mathrm{xi}^{\mathrm{I}}$ & $873 \times 888$ & $\mathrm{~S}_{1507}$ & New Minster, Winchester & Freols \\
\hline s. $\mathrm{xi}^{\mathrm{I}}$ & $78 \mathrm{I}$ & $\mathrm{S}_{\mathrm{I} 257}$ & Worcester & Freols \\
\hline s. $\mathrm{xi}^{\mathrm{I}}$ & After $822-3$ & $\mathrm{~S}_{\mathrm{I} 432}$ & Worcester & Freodom \\
\hline S. $\mathrm{xi}^{\mathrm{I}}$ & $88_{3}$ & $\mathrm{~S}_{2 \mathrm{I}} 8$ & Worcester & Freodom \\
\hline
\end{tabular}

